\title{
Emergence and initial growth of rambutan seedlings as a function of seed storage conditions
}

\author{
Ítalo Herbert Lucena CAVALCANTE ${ }^{1,2 *}$, Adriano SEgeren ${ }^{1}$, Antonio Baldo Geraldo MARTINS ${ }^{1}$
}

${ }^{1}$ Dep. Phytotech., Fac. Agric. Vet. Sci., São Paulo State Univ., Jaboticabal, São Paulo, Brazil

italohlc@ufpi.edu.br

${ }^{2}$ Dep. Agron., Fed. Univ. Piauí, Campus Profr. Cinobelina Elvas, Bom Jesus, Piauí, Brazil

${ }^{*}$ Correspondence and reprints

Fruits, 2008, vol. 63, p. 349-355 (C) 2008 Cirad/EDP Sciences All rights reserved DOI: 10.1051/fruits:2008031 www.fruits-journal.org

RESUMEN ESPAÑOL, p. 355

\section{Emergence and initial growth of rambutan seedlings as a function of seed storage conditions.}

Abstract - Introduction. Rambutan is a tropical fruit species with recalcitrant seeds. Despite the expansion of exotic fruit cultivation in Brazil, lots of which fruit species, including rambutan, need basic information, especially in relation to propagation and storage of seeds, which are important for genetic improvement studies, maintenance of genetic sources and seedling production. Materials and methods. A completely randomized design was adopted with treatments distributed in a factorial arrangement, $3 \times 4$, referring to three seed storage conditions [room temperature conditions; a dry chamber with $(18 \pm 2)^{\circ} \mathrm{C}$ and $60 \%$ relative humidity; and a cold chamber with $(10 \pm 2){ }^{\circ} \mathrm{C}$ and $70 \%$ relative humidity] and four storage times $(0,7,14$ and $21 \mathrm{~d})$. Each treatment of 10 seeds was replicated five times. Data on seedling emergence, emergence rate, plant height, number of leaves and length of main root were submitted to variance analysis and means were separated using Tukey's test. Correlation analysis between seed moisture and seedling emergence was performed. Results and discussion. Our results indicated that dry chamber conditions promoted the statistically significantly highest seedling emergence after $7 \mathrm{~d}$ of storage. Cold chamber conditions promoted an extremely low seedling emergence independently of time. Conclusion. Rambutan seeds can be stored in a dry chamber for $7 \mathrm{~d}$ without losing viability; after $14 \mathrm{~d}$ of storage the loss of emergence is $60 \%$.

Brazil / Nephelium lappaceum / seeds / seed storage / emergence

\section{Émergence et début de croissance de la plantule de ramboutan en fonction des conditions de stockage de la graine.}

Résumé - Introduction. Le ramboutan est une espèce fruitière tropicale à graines récalcitrantes. En dépit de l'extension de la culture des espèces fruitières exotiques au Brésil, de nombreuses espèces, y compris le ramboutan, auraient besoin de davantage de connaissances de base quant à leur multiplication et au stockage des graines, ce qui est nécessaire aux études d'amélioration génétiques, à l'entretien des ressources génétiques et à la production de plantules. Matériel et méthodes. Un dispositif complètement randomisé a été adopté avec des traitements disposés selon un arrangement factoriel $3 \times 4$ défini par trois conditions de stockage des graines [condition ambiante ; pièce sèche avec $(18 \pm 2)^{\circ} \mathrm{C}$ et $60 \%$ d'humidité relative ; pièce froide avec $(10 \pm 2)^{\circ} \mathrm{C}$ et $70 \%$ d'humidité relative] et par quatre durée de stockage des graines $(0,7,14$ et 21 jours) ; chaque traitement a porté sur 10 graines et a été répété cinq fois. Les données obtenues portant sur l'émergence de la plantule, le taux de germination des graines, la hauteur du jeune plant, le nombre de feuilles et la longueur de la racine principale ont été soumises à une analyse de variance et la séparation des moyennes a été effectuée en utilisant le test de Tukey. Une analyse des corrélations entre le taux d'humidité de la graine et l'émergence de la plantule a été effectuée. Résultats et discussion. Nos résultats indiquent que les conditions de la pièce sèche ont statistiquement favorisé l'émergence des plantules pour les graines ayant subi 7 jours de stockage. En pièce froide, quelle que soit la durée, l'émergence a été faible. Conclusion. Les graines de ramboutan peuvent être stockées en pièces sèches pendant 7 jours sans que leur viabilité ne soit affectée ; après 14 jours de stockage, la perte d'émergence est de $60 \%$

Brésil / Nepbelium lappaceum / graine / stockage des semences / levée 


\section{Introduction}

Rambutan (Nephelium lappaceum L.) is a tropical attractive, nutritious [1] and delectable fruit of the Sapindaceae family closely related to lychee. The tree is considered to be native to Malaysia and Indonesia, despite van Welzen and Verheij's [2] report that its origin is untraceable because escapees from cultivation blur the original distribution. The species is also common in Australia, the Caribbean, India, Sri Lanka, the USA (Florida and Hawaii) and Central America [3]; in Brazil, although rambutan trees have been recently introduced, there are commercial orchards in Amazonas, Bahia and São Paulo States [4].

In spite of the expansion of fruit tree cultivation in Brazil, many exotic fruit species, including rambutan, need basic information about plant propagation, physiology and nutrition, as Vanderlinden et al. [5] also observed in studies about rambutan realized in Mexico. Thus, research work aiming at studying possible conditions in which to store rambutan seeds is important to the expansion of exotic fruiticulture in Brazil

Rambutan trees can be propagated by vegetative and/or sexual methods [4, 6]. Seed propagation of rambutan has been the traditional practice: a large number of trees in production throughout South-East Asia were originated from seeds. Thus, seed propagation of rambutan should be used for development of new varieties and rootstocks [7].

Seeds of rambutan are recalcitrant [8], i.e., they do not tolerate drying after seed development and require special changes in storage because they are short-lived [6]. Hence, seeds have to be sown immediately after ripening because, when seeds are sown after (3 to 4) weeks, they usually do not germinate [7]. However, there is no recommendation in the scientific literature for a storage method of rambutan seeds that provides seed viability and avoids seed deterioration, which has been necessary for some time for genetic improvement and propagation studies. In this area, the objective of our study was to evaluate the emergence and initial growth of rambutan seedlings as a function of seed storage.

\section{Materials and methods}

\subsection{Plant materials}

Seeds of rambutan (Nephelium lappaceum), an exotic fruit species in Brazil, were manually extracted from mature fruits released from rambutan plants formed by seed propagation. These plants, belonging to the Germplasm Active Bank of São Paulo State University (Brazil), were cultivated without specific management for fertilization, pruning, irrigation and control of pests and diseases. The local climate is classified as Cwa with an average precipitation of $1400 \mathrm{~mm} \cdot$ year $^{-1}$ and average temperatures between $18.5^{\circ} \mathrm{C}$ and $25.0^{\circ} \mathrm{C}$.

\subsection{Growth conditions and experimental design}

The experiment was carried out, under 50\% of luminosity, in a canvassed shelter of the Faculty of Agrarian and Veterinarian Sciences, São Paulo State University (Jaboticabal, Brazil).

A completely randomized design was adopted with treatments distributed in a factorial arrangement, $3 \times 4$, referring to three seed storage conditions: room temperature and relative humidity (RH); a dry chamber [(18 \pm 2$)^{\circ} \mathrm{C}$ and $60 \%$ of $\left.\mathrm{RH}\right]$; and a cold chamber $\left[(10 \pm 2){ }^{\circ} \mathrm{C}\right.$ and $70 \%$ of $\left.\left.\mathrm{RH}\right)\right]$, and four storage times $[(0,7,14$ and 21$) \mathrm{d}]$, with five repetitions of 10 seeds each, with a total of 600 seeds.

After extraction, the seeds were put immediately in paper bags and stored for a pre-established time at the laboratory of Seed Technology; then, according to Hartmann et al.'s [6] recommendations, they were horizontally sown at 4-cm depth in a seedbed measuring $100 \mathrm{~cm}$ in height and $300 \mathrm{~cm}$ in width filled with washed sand. Rambutan seeds were sown in parallel rows of 10 seeds at approximately $5-\mathrm{cm}$ intervals and irrigated once daily with good quality water $(\mathrm{pH}=6.8$, electrical conductivity $=$ $\left.0.3 \mathrm{dS} \cdot \mathrm{m}^{-1}\right)$ by a microsprinkler irrigation system (Amanco, São Paulo, Brazil).

Two batches of 10 seeds were dried at $(105 \pm 3)^{\circ} \mathrm{C}$ for $24 \mathrm{~h}$ to determine the initial 
moisture of seeds (34.71\%) [9]. Seed moisture was also determined after storage in each chamber on each date.

When seedlings appeared visibly from the substrate surface they were considered as emerged, and counted. After sowing, seedling emergence was monitored at 2-d intervals.

\subsection{Variables registered and statistical analyses}

At the end of the experiment, the emergence percentage (\%) and emergence rate (\%) were determined by the speed emergence method proposed by Maguire [10]. The variables plant height $(\mathrm{cm})$, number of leaves and length of main root $(\mathrm{cm})$ were determined at the end of the experiment $(15 \mathrm{~d}$ after sowing).

Statistical analyses included analysis of variance (ANOVA), mean separation of seedling emergence percentage and emergence rate data using Tukey's test, and correlation analysis between seed moisture and seedling emergence of each storage condition [11]. All the calculations were performed using the SAS Statistical Program [12] and terms were considered significant at $P<0.01$.

\section{Results and discussion}

Seedling emergence of rambutan seeds was remarkably affected by both time and conditions of storage, as previously expected. Seedling emergence was not registered at any time, independently of storage conditions, i.e., after $21 \mathrm{~d}$ of storage no seedlings emerged (figure 1).

Under room conditions of storage, most seedlings emerged as soon as they were extracted from fruits (almost 100\%) and were significantly reduced, nearly $40 \%$, at $7 \mathrm{~d}$ of storage; that is close to $50-65 \%$ range reported by Morton [13] after the same time of storage. The same author observed average seed germination varying from $87 \%$ to $95 \%$ of seeds sowed at $2 \mathrm{~d}$ after extraction,

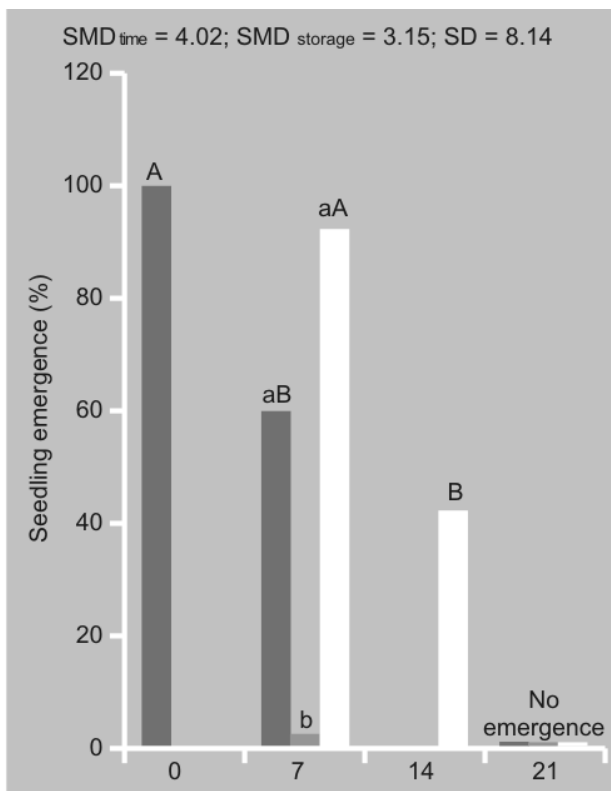

Figure 1.

Seedling emergence and emergence rate of rambutan seedlings as a function of conditions (minor letter on the same storage time) and time (capital letter comparing the same conditions for different times) of storage.

(SMD = Significant Minimum Difference; SD = Standard Deviation; bars with the same letter do not differ by Tukey's test at 0.01 probability error).

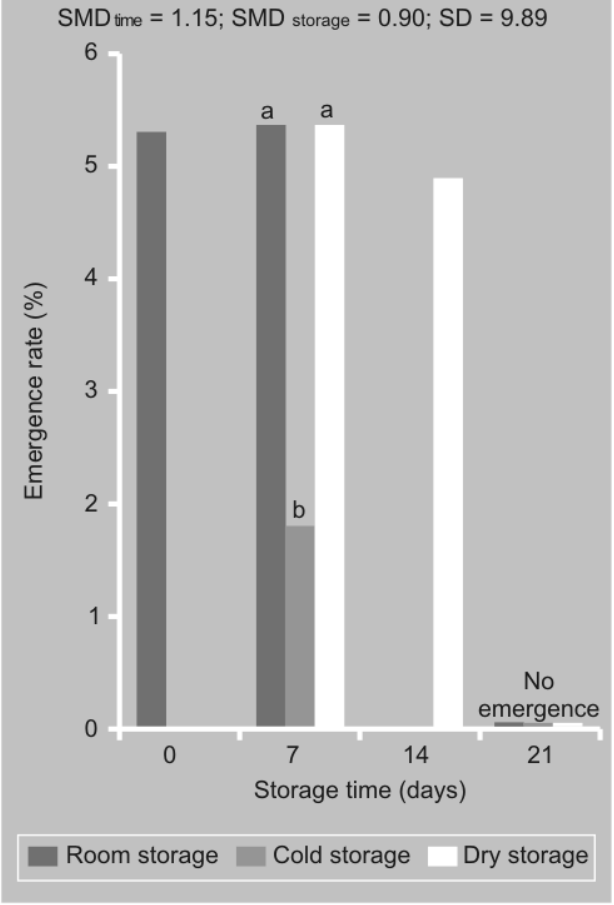

and is thus in agreement with the present study.

Rambutan seeds stored in the cold chamber emerged only at $7 \mathrm{~d}$ of storage with a strong and statistically low percentage (figure 2). On the other hand, at this time, dry chamber storage promoted the highest 
Figure 2.

Correlation between seedling emergence and seed moisture of rambutan seeds as a function of conditions (room storage, dry storage and cold storage) and time of storage.
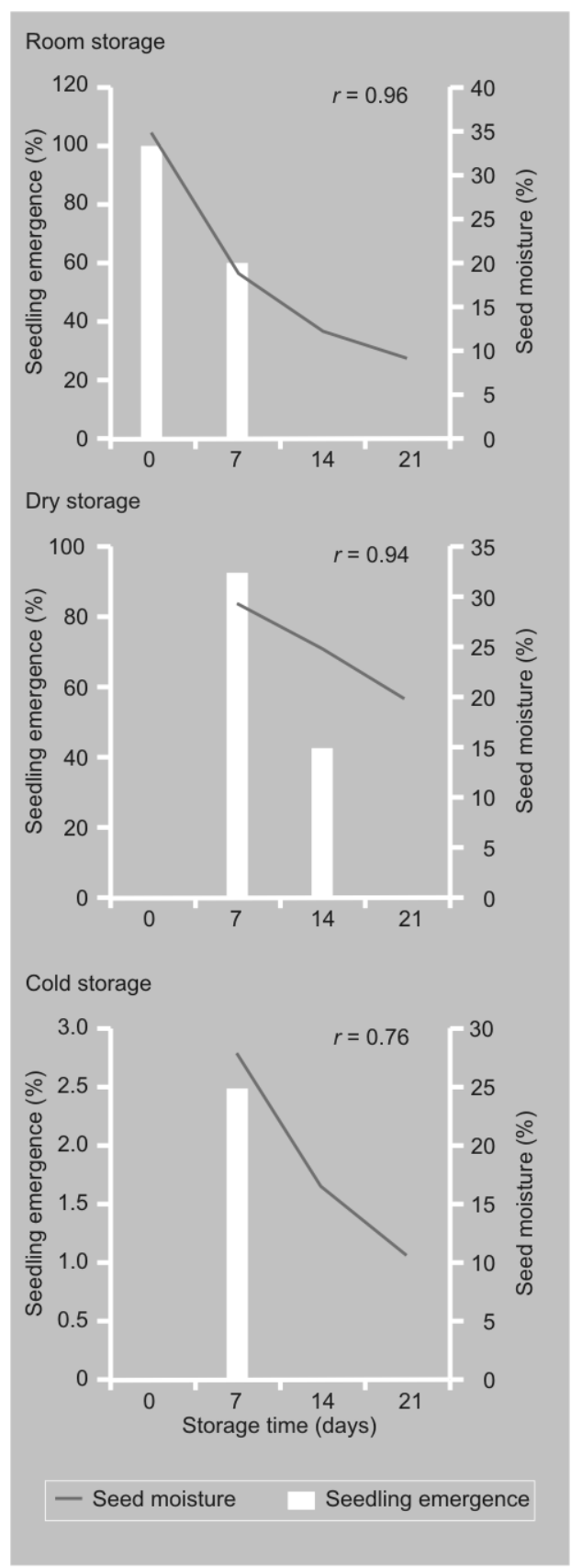

and most significant seedling emergence in relation to storage under room conditions, showing that dry chamber storage is efficient for maintenance of seed vigor for at least $7 \mathrm{~d}$.

Studies regarding the correlation between seedling emergence and seed moisture of seeds stored in room conditions, dry chamber and cold chamber showed that seedling emergence was reduced invariably with time elapsing, independently of storage conditions (figure 2); this was also observed for seed moisture, which confirms the valuable importance of seed moisture for rambutan seedling emergence, previously reported by Morton [13], Arora and Rao [7], and Teng [8]. In addition, Hartmann et al. [6] explain that controlling seed moisture content is probably the most important factor in seed longevity and storage.

Room storage from $0 \mathrm{~d}$ to $7 \mathrm{~d}$ of storage promoted a reduction in seed moisture from $34.77 \%$ to $18.81 \%$, correlated with seedling emergence with a significant $(P<0.01)$ correlation coefficient $(r$ ) of 0.96 (figure 2).

Horn [14] verified that emergence of recalcitrant seeds cannot take place at low levels of moisture, which is an important basis for maintaining viability and controlling emergence. Additionally, soil/substrate temperature and water potential are the major driving factors for seed germination and seedling emergence under controlled and natural environments.

Recalcitrant seeds, such as rambutan, cannot be dried below rather high levels of moisture (25\% to 50\%). Seed moisture contents are not quite as high, but they are much higher than those that are found in species with dry fruits. Some examples of seed moisture contents from fleshy fruits at shedding are flowering dogwood, a drupe (34\%), and persimmon (Diospyros virginiana), a berry (50\%) [15]. Rambutan has been poorly studied, especially in Brazil, making it difficult to find references to compare with the data of the present work.

It is important to note the conditions of storage, because the dry chamber presented $42.5 \%$ of seedling emergence with seed moisture of $26.24 \%$, while in the cold chamber $2.5 \%$ of emerged seeds were registered, with $28.25 \%$ of moisture (figure 2).

As also observed for seedling emergence, the emergence rate was statistically influenced by the storage conditions at $7 \mathrm{~d}$ of storage, also with a lower rate for the cold chamber, i.e., the seedlings emerged in a longer time, or more slowly than in other 
storage conditions. In a study about another fruit species, dovyalis (Dovyalis caffra, also with recalcitrant seeds), Oliveira et al. [16] observed that the highest emergence rate was observed for seeds stored for $14 \mathrm{~d}$, independently of the storage conditions. Cavalcante et al. [17] registered for recalcitrant seeds of white sapote (Cassimiroa edulis) an emergence rate drastically lower $(0.8 \%)$ than any average of the present work.

At $7 \mathrm{~d}$ of storage, seeds stored in the dry chamber originated a significantly higher number of seedlings than those stored in room conditions (figure 3). In general, when individually compared, the time of storage reduced seedling growth, which finds resonance with Morton [13], who concluded that the shorter the seedling emergence, the more vigorous the seedling.

Emerged seedlings of both room and dry chamber storage conditions presented leaves and, following the results registered for plant height, the seedling that emerged first also presented more leaves (figure 3). Hartmann et al. [6] state that two-leaved seedlings are produced within 2 weeks after sowing, a result that agrees with our study.

In relation to length of the main root (figure 3), a different data distribution was observed for room storage conditions, i.e., seeds that were stored for $7 \mathrm{~d}$ promoted seedlings with longer roots. Continued development and growth of the plant following successful seed germination is dictated by external environmental factors such as light and temperature, and by complex interactions with endogenous phytohormones including GA (gibberellic acid), ABA (abscisic acid), cytokinin and auxin [18].

Despite the higher seedling emergence of the dry chamber at $7 \mathrm{~d}$ of storage (figure 1), room storage conditions presented longer roots. According to Hartmann et al. [6], external conditions are important and act differently on seedling emergence. The same authors conclude that the optimum temperature or moisture for seedling emergence may be different from the temperature for optimal seedling growth.

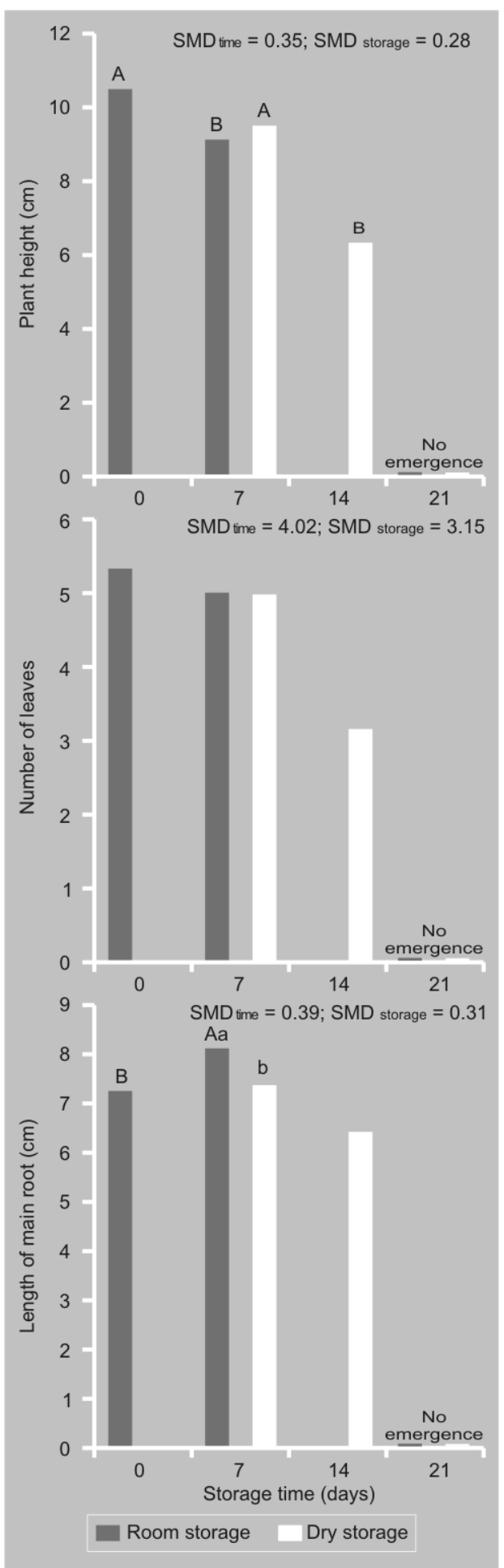

Figure 3.

Plant height, number of leaves and length of main root of rambutan seedlings as a function of conditions (minor letter on the same storage time) and time (capital letter comparing the same conditions for different times) of storage. (SMD = Significant Minimum Difference; bars with the same letter do not differ by Tukey's test at 0.01 probability error.) 


\section{Conclusions}

The results of our study indicate that: (a) storage conditions affect seedling emergence of rambutan; (b) rambutan seeds can be stored in a dry chamber for $7 \mathrm{~d}$ without losing viability; (c) after $14 \mathrm{~d}$ of storage, the loss of seedling emergence is 60\%.

\section{References}

[1] Wall M.M., Ascorbic acid and mineral composition of longan (Dimocarpus longan), lychee (Litchi chinensis) and rambutan (Nephelium lappaceum) cultivars grown in Hawaii, J. Food Compos. Anal. 19 (2006) 655-663.

[2] Van Welsen P.C., Verheij E.W.M., Nephelium lappaceum, in: Verheij E.W.M., Coronel R.E. (Eds.), Plant resources of South-East Asia, Pudoc, Wageningen, Netherlands, 1991.

[3] Zee F.T., Chan H.T. Jr., Yen C.R., Lychee, longan, rambutan and pulasan, in: Shaw P.E., Chan Jr H.T., Nagy S. (Eds.), Tropical and subtropical fruits, Agscience, Aburndale, USA, 1998.

[4] Lorenzi H., Bacher L., Lacerda M., Sartori S., Brazilian fruits and cultivated exotics, Plantarum, São Paulo, Brazil, 2006.

[5] Vanderlinden E.J.M., Pohlan H.A.J., Janssens M.J.J., Culture and fruit quality of rambutan (Nephelium lappaceum L.) in the Soconusco region, Chiapas, Mexico, Fruits 59 (2004) 339-350.

[6] Hartmann H.T., Kester D.E., Davies Jr. F.T., Geneve R.L., Plant propagation: principles and practices, 7th ed., Prentice Hall, New Jersey, USA, 2002.
[7] Arora R.K., Rao V.R., Tropical fruits in Asia: diversity, maintenance, conservation and use, IPGRI, Bangalore, India, 1997.

[8] Teng Y.T., Effect of drying on the viability of rambutan and durian seeds, Mardi Res. Bul. 5 (1977) 111-113.

[9] Anon., Regras para análise de sementes, Minist. Agric. Reforma Agrár., SNDA/DNDV/ CLAV, Brasília, Brazil, 1992.

[10] Maguire J.D., Speed of germination - aid in selection aid in evolution for seedling emergence and vigor, Crop Sci. 2 (1962) 176-177.

[11] Ferreira P.V.F., Estatística experimental aplicada à agronomia, EDUFAL, Maceió, Brazil, 2000.

[12] Anon., SAS/STAT User's Guide, version 4.0.2., SAS Inst. Inc., Cary, USA, 2000.

[13] Morton J., Rambutan, in: Morton J. (Ed.), Fruits of warm climates, Miami, USA, 1987, pp. 262-265.

[14] Horn W., Zierpflanzenbau, Blackwell, Berlin, Germany, 1996.

[15] Salunkhe D.K., Kadam S.S., Fruit science and technology, Marcel Dekker, New York, USA, 1995.

[16] Oliveira I.V.M., Cavalcante Í.H.L., Martins A.B.G., Armazenamento de sementes de doviális (Dovyalis caffra), Rev. Bras. Frutic. 28 (2006) 539-541.

[17] Cavalcante Í.H.L., Oliveira I.V.M., Beckmann-Cavalcante M.Z., Martins A.B.G., Substrate for seedling emergence in Brazil, Am. J. Plant Sci. Biotech. 2 (2008) 47-50.

[18] Heggie L., Halliday K.J., The highs and lows of plant life: temperature and light interactions in development, Int. J. Biol. 49 (2005) 675-687. 


\section{Emergencia y principio de crecimiento de la plántula de rambután en función de las condiciones de almacenamiento de la semilla.}

Resumen - introducción. El rambután es una especie frutera tropical de semillas persistentes. A pesar de la extensión del cultivo de las especies fruteras exóticas en Brasil, muchas especies, entre ellas el rambután, necesitarían más conocimientos básicos en cuanto a su multiplicación y al almacenamiento de las semillas, lo que es necesario tanto para los estudios de mejora genéticos como para el cuidado de los recursos genéticos, o incluso para la producción de plántulas. Material y métodos. Se adoptó un dispositivo completamente randomizado con tratamientos dispuestos según un orden factorial $3 \times 4$ definido tanto por tres condiciones de almacenamiento de las semillas [condición ambiente; espacio seco con $(18 \pm 2){ }^{\circ} \mathrm{C}$ y $60 \%$ de humedad relativa; espacio frío con $(10 \pm 2){ }^{\circ} \mathrm{C}$ y $70 \%$ de humedad relativa] como por cuatro duraciones de almacenamiento de semillas [(0, 7, 14 y 21) días]. Cada tratamiento se realizó con 10 semillas y se repitió cinco veces. Se sometieron a un análisis de varianza los resultados obtenidos en relación a la emergencia de la plántula, al índice de germinación de las semillas, a la altura de la plántula joven, al número de hojas y a la longitud de la raíz principal. Asimismo se efectuó la separación de los valores medios, mediante el estadístico de Tukey. Se efectuó un análisis de las correlaciones entre los índices de humedad de la semilla y la emergencia de la plántula. Resultados y discusión. Nuestros resultados indican que las condiciones del espacio seco favorecieron estadísticamente la emergencia de las plántulas para las semillas de 7 días de almacenamiento. En espacio frío, independientemente de la duración, la emergencia fue débil. Conclusión. Se pueden almacenar las semillas de rambután en espacios secos durante 7 días sin que afecte su viabilidad; tras 14 días de almacenamiento, la pérdida de emergencia es del $60 \%$.

Brasil / Nephelium lappaceum / semilla / almacenamiento de semillas / emergencia 